Bangladesh J. Bot. 47(4): 961-967, 2018 (December)

\title{
IN VITRO MICROPROPAGATION IN TROPICAL SHORT DAY ONION (ALLIUM CEPA L.)
}

\author{
Rupali Passi, AS Dhatt and MK Sidhu* \\ Department of Vegetable Science, Punjab Agricultural University, Ludhiana-141 004, India
}

Keywords: Micropropagation, Varieties, Growth hormone, Onion

\begin{abstract}
For in vitro micropropagation, short day tropical varieties of onion 'Agrifound Dark Red', 'Punjab Naroya' and 'PRO-6' were exposed to different concentrations and combinations of growth hormones. Pre-sterilization of basal plate of onion in $0.5 \%$ solution of bavistin followed by treatment with $0.1 \%$ mercuric chloride for 10 min. produced the highest rate of survival of explants (47.9\%). Survival was further enhanced to $53.17 \%$ with the addition of $750 \mathrm{ppm}$ cefotaxime in MS medium. Varietal differences were observed for in vitro establishment, multiplication and root induction. Among various combinations of growth hormones, MS medium supplemented with $4.0 \mathrm{mg} / \mathrm{l}$ BAP + $0.5 \mathrm{mg} / \mathrm{l} \mathrm{NAA,} 2 \mathrm{mg} / \mathrm{l}$ BAP and $0.5 \mathrm{mg} / \mathrm{l}$ NAA and half MS carrying $1.0 \mathrm{mg} / \mathrm{l} \mathrm{IBA}+0.5 \mathrm{mg} / \mathrm{l}$ NAA produced the highest in vitro establishment (53.07\%), multiplication (64.46\%) and rooting (66.37\%) respectively, in 'Agrifound Dark Red'.
\end{abstract}

\section{Introduction}

Onion (Allium cepa L.) is multiplied through seed or sets and requires two-years to complete one seed cycle necessitating the dependence on huge resources and the involvement of high risks (Sidhu et al. 1992). Poor seed viability, very high out crossing, bulblet formation, dormancy in plantlets, vitrification of tissues and decrease in regenerability for natural vegetative multiplication are some of the limitations in propagation of onion in the open field. Other members of Allium family are propagated vegetatively and have high in vivo and in vitro regeneration potential as reported in garlic (Robledo-Paz et al. 2000, Haque et al. 2003, Luciani et al. 2006) and Allium wallichii (Wawrosch et al. 2001) and Allium chinense (Xu et al. 2008). Although, there are reports on in vitro callus induction (Martinez et al. 2000), shoot regeneration (Khalid et al. 2001) and micropropagation (Pike and Yoo 1990, Kahane et al. 1992) in long day onion, but little information is available for large scale production of regenerated seedlings. India is the largest producer of short day onion and this crop is grown all over the country in two seasons viz. over winter and late summer. Keeping in view the significance of micropropagation for maintenance and multiplication of elite varieties, the present study was planned to study the effect of varieties from both the growing seasons and growth hormones on in vitro multiplication of shoots in short day onion.

\section{Materials and Methods}

In this investigation, meristem and basal plate excised from the bulbs of three onion varieties viz. 'Punjab Naroya', 'PRO-6' (both of over winter season) and 'Agrifound Dark Red' (late summer season) were used as explants and cultured on Murashige and Skoog (1962) medium supplemented with different levels of BAP (1.0, 2.0, 3.0, 3.5, 4.0 and $5.0 \mathrm{mg} / \mathrm{l})$ and NAA $(0.1,0.2$ and $0.5 \mathrm{mg} / \mathrm{l}$ ) maintained at $\mathrm{pH} 5.8$. To check the bacterial contaminations in the cultures, the lukewarm MS media a fter autoclaving was also fortified with 200, 500 and $700 \mathrm{ppm}$ cefotaxime

\footnotetext{
*Author for correspondence: <mksidhu@pau.edu>.
} 
$\left(\right.$ Omnatax $\left.^{\mathrm{TM}}\right)$. Both the explants were immersed in $2 \%$ teepol solution for $20 \mathrm{~min}$, washed in running tap water for $10 \mathrm{~min}$ and thoroughly wiped with a cotton swab. To check fungal infections, explants were also treated with $0.5 \%$ bavistin for $15 \mathrm{~min}$ and followed by $30 \mathrm{sec}$ treatment with $70 \%$ ethanol. Further, the surface sterilization was carried out under aseptic conditions (Laminar Air Flow Cabinet) with 0.1 and $0.2 \%$ mercuric chloride and 25 and 50\% commercial bleach (chemical composition: sodium hypochlorite $4.0 \%$ and sodium hydroxide $1.0 \%$ ) as per the durations mentioned in Table 1 . The explants were washed with sterile water for 3 - 4 times to remove excessive disinfectants. The sterilized explants were cultured on establishment media and incubated at $25 \pm 2^{\circ} \mathrm{C}$ under 16 hrs photoperiod (illuminated with $40 \mathrm{~W}$ white fluorescent tubes) followed by 8 hrs dark period. The data were recorded on per cent asepsis and establishment of cultures in vitro after four weeks of inoculation. The sprouts obtained from established explants were gradually separated and sub-cultured after 30 days on MS medium supplemented with different concentrations and combinations of cytokinins (BAP @ 1.0, 2.0 and $3.0 \mathrm{mg} / \mathrm{l}$ and Kn @ $0.5 \mathrm{mg} / \mathrm{l}$ ) and auxin (NAA @ $0.5 \mathrm{mg} / \mathrm{l}$ ) for in vitro shoot multiplication (Table 2). The average number of shoots derived at the end of each subculture out of a single propagule was regarded as the multiplication fold and expressed in per cent. The multiple shoot clumps were separated into individual shoots and cultured on half strength MS medium supplemented with different combinations and concentrations of IBA (0.5, 1.0, 1.5 and $2.0 \mathrm{mg} / \mathrm{l})$ and NAA (0.5 mg/l) as presented in Table 3. For elongation of roots and hardening of plantlets, freshly developed roots were thoroughly washed in running tap water and kept on half strength MS media (without sugar and vitamins) in open glass jars and plastic trays under high light intensity for 4 - 5 days in the incubation room. Fully-grown hardened plants were transferred to polythene bags containing growth media and kept in glass house for $10-12$ weeks at $30 \pm 1{ }^{\circ} \mathrm{C}$ and $80 \pm 2 \% \mathrm{RH}$.

For in vitro establishment, multiplication and rooting, 30 explants were used in each treatment and the cultures were repeated thrice. Data in per cent were converted to arc sine value for analysis of variance (ANOVA). The data were analyzed according to completely randomized design (Snedecor and Cochran 1967) with the help of CPCS-1 software package (Cheema and Singh 1990). Significance of variation among treatments was observed and the results were compared with least square differences.

\section{Results and Discussion}

The surface sterilization of explants at different concentration of mercuric chloride ( 0.1 and $0.2 \%$ ) and commercial bleach (25 and 50\%) for variable time intervals are presented in Table 1. Surface sterilization with $0.1 \%$ mercuric chloride for 10 min brought highest survival (42.88\%) of clean cultures followed by $12(39.61 \%)$ and $8(25.21 \%)$ min durations with same concentration, respectively. The increase in mercuric chloride concentration to $0.2 \%$ lowered the survival rate. The maximum survival with commercial bleach was $16.63 \%$ only. The effectiveness of mercuric chloride as explant sterilization agent has been reported in onion (Pandey et al 1992, Kamstaityte and Stanys 2004) and safed musli (Purohit et al. 1994). The concentration and duration of sterilization treatment depend upon the degree of contamination, type and hardiness of explants also. Treatment with $0.5 \%$ bavistin before surface sterilization with mercuric chloride further increased the survival per cent (Fig. 1). The elimination of fungal contamination with fungicides was substantiated with the report in onion (Khar et al. 2005). The fortification of MS medium with cefotaxime (Omnatax ${ }^{\mathrm{TM}}$ ) was also effective in lessening the bacterial contaminations (Fig. 2). Among various concentrations, the addition of $750 \mathrm{ppm}$ cefotaxime in MS medium augmented the clean cultures to $53.17 \%$. No toxic effect was observed in the range of tested concentrations of cefotaxime. Use of antibiotics to suppress endophytic bacteria has earlier been reported in Crythanthus spp. (Moran et al. 2002). 
Meristem explants cultured on establishment medium (BAP and NAA) showed regeneration within 6 - 8 days of culture initiation, but regenerated shoots started necrosis within 2 - 4 days of establishment and subsequently tissue became dead on all the tested media compositions (Plate 1 A, B and C). Hence, meristem cultures could not be used for further establishment.

\section{Table 1. Effect of disinfectants on survival of explants (\%) in onion.}

\begin{tabular}{lccc}
\hline $\begin{array}{l}\text { Sterilizing } \\
\text { agent }\end{array}$ & $\begin{array}{c}\text { Concentration } \\
(\%)\end{array}$ & $\begin{array}{c}\text { Treatment duration } \\
\text { (minutes) }\end{array}$ & $\begin{array}{c}\text { Survival } \\
(\%)\end{array}$ \\
\hline Mercuric chloride & 0.1 & 5 & $14.27(22.16)^{*}$ \\
& & 8 & $25.21(30.12)$ \\
& & 10 & $42.88(40.80)$ \\
& 0.2 & 12 & $39.61(38.99)$ \\
Commercial bleach & & 5 & $23.67(29.09)$ \\
& 25 & 10 & $17.65(24.81)$ \\
& & 5 & $13.78(21.76)$ \\
Control & 50 & 10 & $12.69(20.81)$ \\
LSD $(\mathrm{p}=0.05)$ & & 5 & $16.63(24.04)$ \\
& & 10 & $14.26(22.11)$ \\
& & - & $10.97(19.32)$ \\
& & & $0.96(17.39)$ \\
& & & $0.00(0.00)$ \\
\hline
\end{tabular}

* Figures in parenthesis are arc sine transformed values.

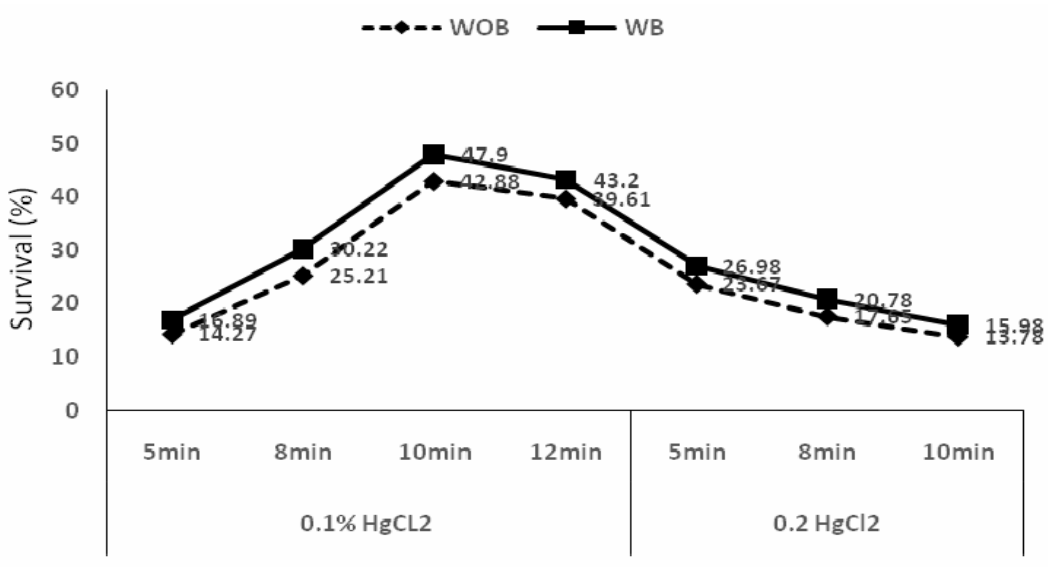

Fig. 1. Effect of pre-sterilization with bavistin on survival (\%) of explants.

The basal plates responded to regeneration and shoot multiplication in onion (Plate $1 \mathrm{D}, \mathrm{E}$ and F). Significant differences were observed among varieties, media and their interactions for establishment of aseptic cultures (Table 2). The highest proliferation (41.56\%) was observed in 'Agrifound Dark Red' followed by 'Punjab Naroya' (37.56\%) and 'PRO-6' (35.43\%). Among media compositions, the maximum basal plate cultures (53.07\%) were established in MS supplemented with $4.0 \mathrm{mg} / \mathrm{l} \mathrm{BAP}+0.5 \mathrm{mg} / \mathrm{l}$ NAA. The interactions between varieties and growth regulators depicted 55.52\% establishment in ADR in MS having $3.5 \mathrm{mg} / \mathrm{l} \mathrm{BAP} \mathrm{+} 0.5 \mathrm{mg} / \mathrm{l} \mathrm{NAA}$. 
However, maximum proliferation in Punjab Naroya (55.36\%) and PRO-6 (48.46\%) was achieved on MS with $4.0 \mathrm{mg} / \mathrm{l} \mathrm{BAP}+0.5 \mathrm{mg} / \mathrm{l}$ NAA. The effectiveness of BAP and NAA supplemented media for proliferation was in accord with the reports in onion (Pike and Yoo 1990) and other monocot bulbous species like Chive (Pandey et al. 1992), garlic (Haque et al. 1998) and Crinum macowani (Slabbert et al. 1993).

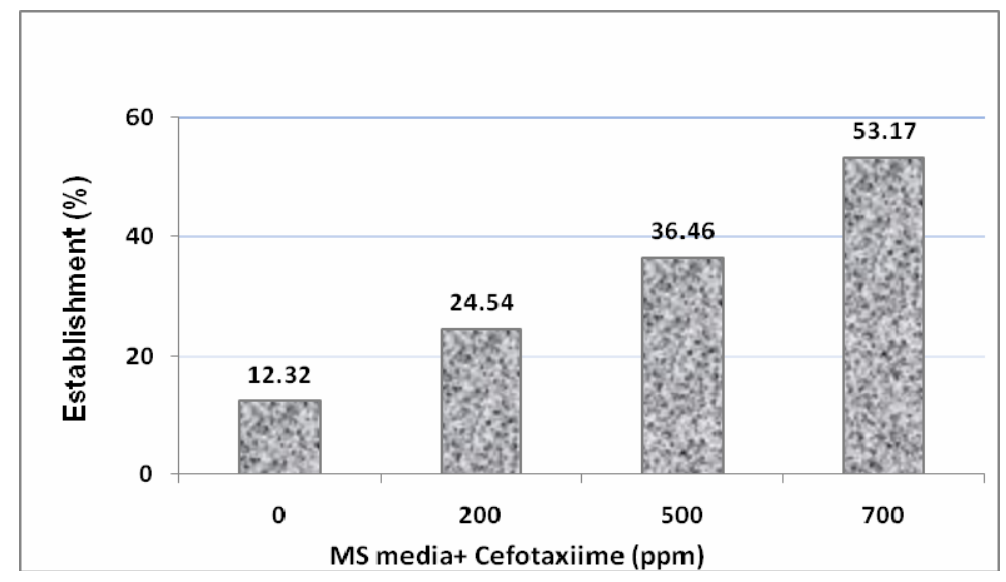

Fig. 2. Effect of cefotaxime on establishment of onion cultures.
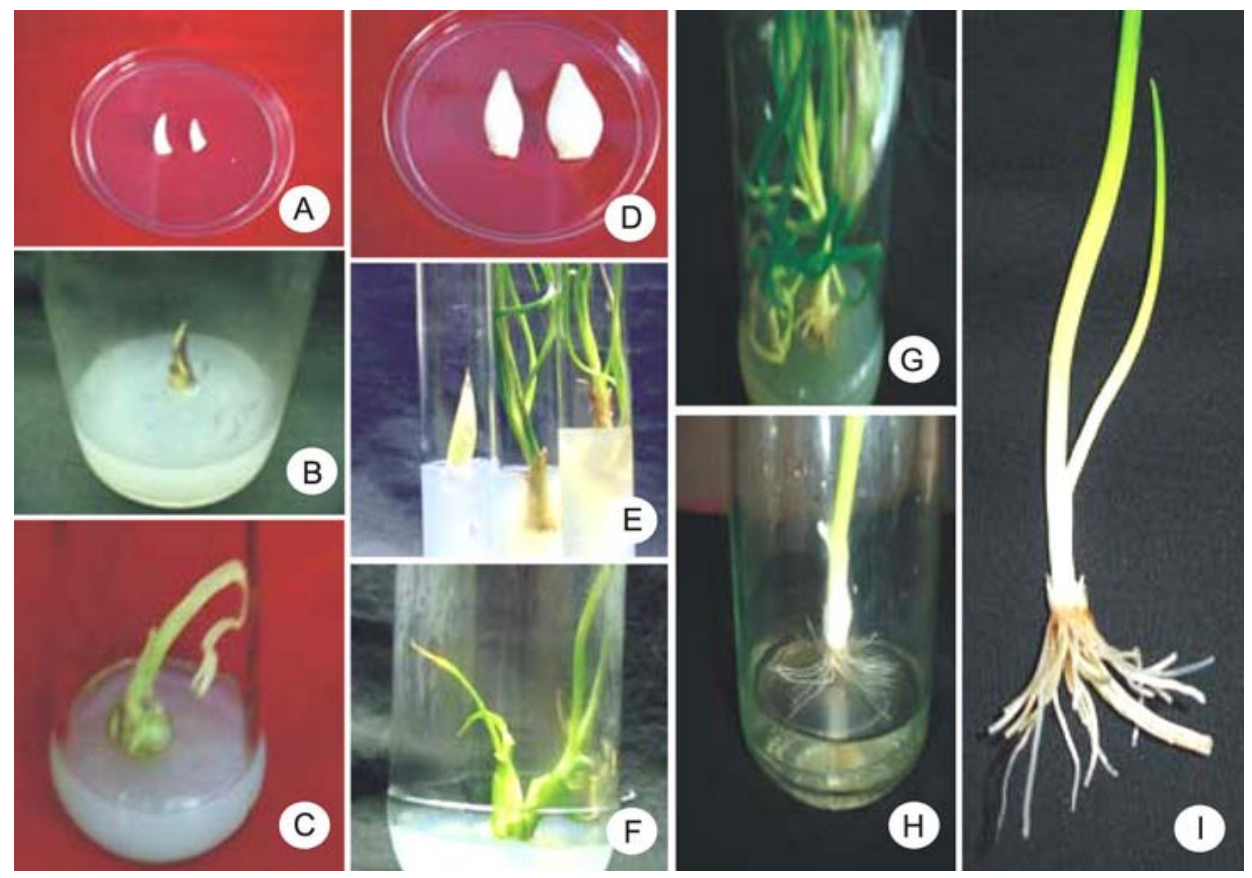

Plate 1. Micropropagation in onion A. Meristem, B. Establishment of meristem C. Necrosis of meristem, D. Basal plate, E. Establishment of basal plate, F. Shoot multiplication from basal plate G. Initiation of roots, H. Proliferation of roots and I. Rooted plantlet. 
Table 2. Interactions of varieties and growth hormones for in vitro establishment (\%) of basal plates in onion.

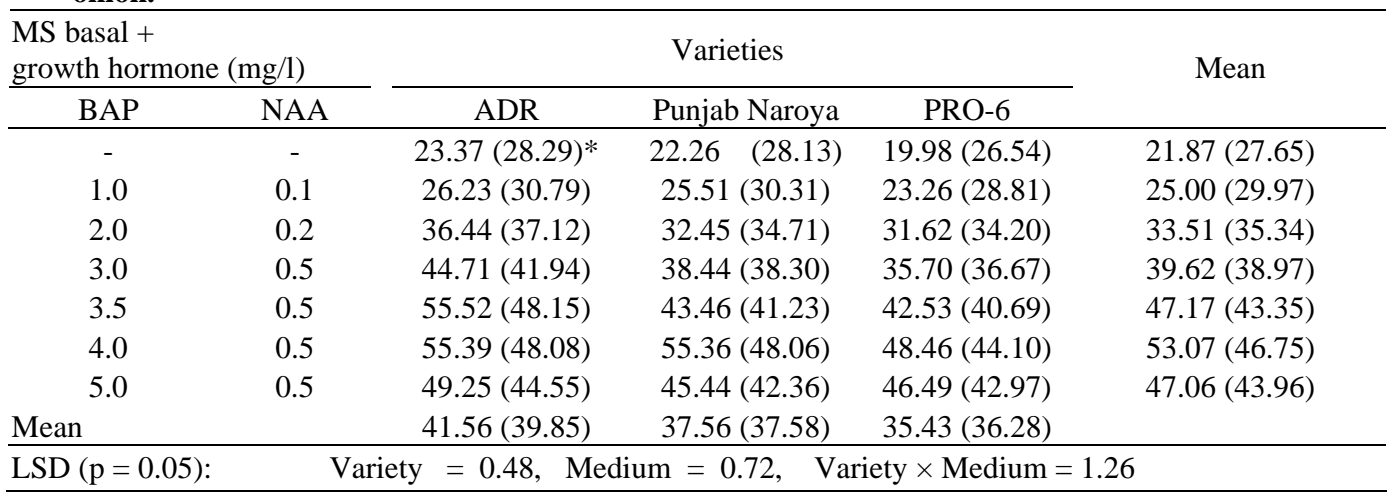

* Figures in parenthesis are arc sine transformed values.

The results of adventitious shoots produced from established basal plates gradually separated and sub-cultured on MS medium supplemented with different combinations of cytokinin and auxin are presented in Table 3. All varieties differed significantly for in vitro shoot multiplication. Cultivar 'ADR' showed highest shoot multiplication (51.11 \%) followed by 'Punjab Naroya' (46.19\%) and 'PRO-6' (41.01 \%). Among media compositions, MS fortified with $2 \mathrm{mg} / \mathrm{l} \mathrm{BAP} \mathrm{+}$ $0.5 \mathrm{mg} / \mathrm{l} \mathrm{NAA}$ and $2 \mathrm{mg} / \mathrm{l} \mathrm{BAP}+0.5 \mathrm{mg} / \mathrm{l} \mathrm{NAA}$ brought maximum proliferation of shoots (64.46 and $63.41 \%$, respectively) with non-significant differences. Interaction effects depicted maximum in vitro shoot multiplication in 'ADR' (72.32\%) and 'Punjab Naroya' (66.29\%) on MS having 2 $\mathrm{mg} / \mathrm{l} \mathrm{BAP}+0.5 \mathrm{mg} / \mathrm{l} \mathrm{NAA}$ and in 'PRO-6' (59.75\%) on MS supplemented with $3 \mathrm{mg} / \mathrm{l} \mathrm{BAP}+0.5$ $\mathrm{mg} / \mathrm{l}$ NAA. The proliferation rate may depend upon the degree of cell differentiation in different varieties and their response towards optimal concentration of growth hormones for its stimulation. The differential response of BAP and NAA for shoot multiplication of different varieties has been reported in onion (Gems and Martinovitch 1998, Kamastaityte and Stanys 2004) and other bulbous species like garlic (Ma et al. 1994 and Haque et al. 1997) and Allium wallichii (Wawrosch et al. 2001).

Table 3. Interactions of varieties and growth hormones for in vitro shoot multiplication (\%) in onion.

\begin{tabular}{|c|c|c|c|c|c|c|}
\hline \multicolumn{3}{|c|}{$\begin{array}{l}\text { MS basal + } \\
\text { growth hormone (mg/l) }\end{array}$} & \multicolumn{3}{|c|}{ Varieties } & \multirow[t]{2}{*}{ Mean } \\
\hline BAP & Kin. & NAA & ADR & Punjab Naroya & PRO-6 & \\
\hline- & - & - & $0.00(0.00)^{*}$ & $0.00(0.00)$ & $0.00(0.00)$ & $0.00(0.00)$ \\
\hline 1.0 & - & 0.5 & $56.64(48.82)$ & $50.68(45.37)$ & $47.28(43.42)$ & $51.53(45.87)$ \\
\hline 2.0 & - & 0.5 & $72.32(58.24)$ & $66.29(54.49)$ & 54.78 (47.73) & $64.46(53.48)$ \\
\hline 3.0 & - & 0.5 & $67.99(55.52)$ & $62.48(52.21)$ & 59.75 (50.63) & $63.41(52.79)$ \\
\hline 4.0 & - & 0.5 & $61.87(51.84)$ & $57.51(49.30)$ & $52.42(46.37)$ & $57.27(49.17)$ \\
\hline 2.0 & 0.5 & - & 46.44 (42.91) & 40.69 (39.60) & 37.85 (37.91) & $41.66(40.14)$ \\
\hline 3.0 & 0.5 & - & $54.22(47.41)$ & $48.00(43.83)$ & 42.89 (40.89) & $48.37(44.04)$ \\
\hline 4.0 & 0.5 & - & $49.43(44.66)$ & $43.90(41.48)$ & 33.08 (35.08) & $42.14(40.41)$ \\
\hline \multicolumn{2}{|l|}{ Mean } & & 51.11 (43.68) & 46.19 (40.79) & 41.01 (37.75) & \\
\hline \multicolumn{2}{|c|}{$\operatorname{LSD}(p=0.05)$} & Variety & 1.06, Medium & $=1.72$, Variety $>$ & Medium $=2.98$ & \\
\hline
\end{tabular}

* Figures in parenthesis are arc sine transformed values. 
In vitro root induction, proliferation and development of rooted plant are presented in Plate 1 $\mathrm{G}, \mathrm{H}$ and $\mathrm{I}$. The varieties, growth hormones and their interactions highlighted significant differences for root induction of micro shoots (Table 4). The highest root induction was observed in 'ADR' (62.07 \%) followed by 'Punjab Naroya' (51.37\%) and 'PRO-6' (37.00\%). The maximum root induction was observed on $1 / 2$ MS supplemented with $1.0 \mathrm{mg} / \mathrm{l} \mathrm{IBA}+0.5 \mathrm{mg} / \mathrm{l}$ NAA (66.37\%). Interactions of varieties and media illustrated highest root induction of micro shoots in 'ADR' (87.37\%) on $1 / 2$ MS with addition of $1.0 \mathrm{mg} / \mathrm{l} \mathrm{IBA}$ and $0.5 \mathrm{mg} / \mathrm{l} \mathrm{NAA}$, followed by 'Punjab Naroya' (75.21 \%) on 1/2 MS with $1.5 \mathrm{mg} / \mathrm{l}$ IBA and $0.5 \mathrm{mg} / \mathrm{l} \mathrm{NAA}$. The least response was shown in 'PRO-6' (51.54 \%) on 1/2 MS supplemented with $1 \mathrm{mg} / \mathrm{l}$ IBA and $0.5 \mathrm{mg} / \mathrm{l} \mathrm{NAA}$. In general, low concentration of organic and inorganic salts ( $1 / 2$ MS or $1 / 4$ MS medium) found better for in vitro induction of roots in large number of plant species. The results of the present study are corroborated with the reports of Dian et al. (2004) and Khar et al. (2005) in welsh onion.

Table 4. Interactions of varieties and growth hormones for in vitro root induction (\%) in onion.

\begin{tabular}{|c|c|c|c|c|c|}
\hline \multicolumn{2}{|c|}{$\begin{array}{l}\text { Half MS basal + } \\
\text { growth hormone (mg/l) }\end{array}$} & \multicolumn{3}{|c|}{ Varieties } & \multirow[t]{2}{*}{ Mean } \\
\hline IBA & NAA & ADR & Punjab Naroya & PRO-6 & \\
\hline- & - & $32.13(34.51)^{*}$ & $25.25(30.15)$ & $17.25(24.51)$ & $24.88(29.72)$ \\
\hline 0.5 & - & $63.21(52.64)$ & 44.4 (41.77) & 34.25 (35.80) & $47.29(43.40)$ \\
\hline 1.0 & 0.5 & 87.37 (69.17) & $60.21(50.87)$ & $51.54(45.87)$ & $66.37(55.30)$ \\
\hline 1.5 & 0.5 & $72.41(58.30)$ & $75.21(60.12)$ & 42.88 (40.89) & $63.50(53.10)$ \\
\hline 2.0 & 0.5 & $55.24(48.00)$ & $51.64(45.93)$ & 39.11 (38.69) & $48.66(44.21)$ \\
\hline Mean & & $62.07(52.52)$ & $51.34(45.77)$ & $37.00(37.15)$ & \\
\hline $\operatorname{LSD}(p=0.05)$ & & Variety $=0.56$, Medium & $=0.72$, Vari & $\times$ Medium $=1.26$ & \\
\hline
\end{tabular}

* Figures in parenthesis are arc sine transformed values.

In vitro propagated plantlets were tender and fragile, thereby hardened on moist cotton with half MS salt for five days in incubation room. The hardened plantlets were transferred to growing media and kept in greenhouse at $25 \pm 1^{\circ} \mathrm{C}$ and $\pm 2 \%$ relative humidity, respectively for further growth.

From the present study, it can be concluded that pre-sterilization of basal plate with $0.5 \%$ bavistin followed by surface sterilization with $0.1 \%$ mercuric chloride for 10 min was most effective to reduce fungal infections in in vitro cultures of onion. Addition of $750 \mathrm{ppm}$ cefotaxime in culture media helped in reducing the systemic and bacterial contaminations. Onion varieties and explants had differential response for in vitro establishment, multiplication and root induction. Basal plates of onion were the best explants and 'Agrifound Dark Red' was best variety for micropropagation in onion. Among media combinations, MS media supplemented with $3.5 \mathrm{mg} / \mathrm{l} \mathrm{BAP}+$ $0.5 \mathrm{mg} / \mathrm{l} \mathrm{NAA}, 2 \mathrm{mg} / \mathrm{l} \mathrm{BAP}$ and $0.5 \mathrm{mg} / \mathrm{l} \mathrm{NAA}$ and half MS carrying $1.0 \mathrm{mg} / \mathrm{l} \mathrm{IBA}+0.5 \mathrm{mg} / \mathrm{l}$ NAA were the best for in vitro establishment, multiplication and rooting in onion, respectively.

\section{References}

Cheema HS and Singh B 1990. A User's Manual to CPCS-1. A Computer Programme Package for the Analysis of Commonly Used Experimental Designs, pp. 1, PAU, Ludhiana.

Dian C, Xiaomei H, Young J and Yan L 2004. Studies on culture and propagation of virus elimination seedling from welsh onion shoot tip. Acta Hort Sinica 31: 673-75.

Gems, JA and Martinovitch L 1998. The effect of TDZ on gynogenesis induction and plant regeneration in onion. Zoldsegtermesztesi Kutato Intezet Bull. 28: 39-45. 
Haque M, Wada T and Hattori K 1997. Garlic roots for micropropagation through in vitro bulbet formation. Acta Hort. 520: 45-52.

Haque M, Wada T and Hattori K 1998. Noval Method of rapid micropropagation using cyclic bulblet formation from root tip explant in garlic. Breeding Sci. 48: 293-299.

Haque, M, Wada, T and Hattori, K 2003. Shoot regeneration and bulbet formation from shoot and root meristem of garlic cv Bangladesh local. Asian J. Plant Sci. 2: 23-27.

Kahane R, Rancillac M and Serve B 1992. Long term multiplication of onion (Allium cepa L) by cyclic shoot regeneration in vitro. Plant Cell Tiss. Org. Cult. 28: 281-288.

Kamastaityte, D and Stanys, V 2004. Micropropagation of onion (Allium cepa L). Acta Universitatis Latviensis Biol. 676: 173-176.

Khalid A, De-ping G and Zhu-jun Z 2001. Effect of growth regulators on plantlet regeneration and bulbing in onion (Allium cepa L.) in vitro. Pakistan J. Biol. Sci. 4(3): 374-377.

Khar A, Bhutani, R and Yadav N 2005. In vitro studies on multiple shoot induction in onion. Indian J. Hort. 62: 94-95.

Luciani GF, Mary AK, Pellegrini C and Curvetto CR 2006. Effects of explants and growth regulators in garlic callus formation and plant regeneration. Plant Cell Tiss. Org. Cul. 87(2): 139-143.

Ma, Y, Wang, H L, Zhang, C J and Kang, Y Q 1994. High rate of virus free plantlet regeneration via garlic scape tip culture. Plant Cell Rep. 14: 65-68.

Martinez L, Aguero C, Lopez M and Galmarini C 2000. Improvement of in vitro gynogenesis induction in onion (Allium cepa L.) using polyamines. Plant Sci. Limerick. 156: 221-22.

Moran G, Colque R, Viladomat F, Bastida J and Codina C 2002. Mass propagation of Cyrthanthus clavatus and Cyrthanthus spiralis using liquid media culture. Sci. Hort. 98: 49-60.

Murashige T and Skoog F 1962. A revised medium for rapid growth and bioasssays with tobacco tissue culture. Physiol. Plant. 15: 473-497.

Pandey R, Chandel K and Rao S 1992. In vitro propagation of Allium tuberosum Rottl. ex. spreng by shoot proliferation. Plant Cell Rep. 11: 375-378.

Pike R and Yoo 1990. A tissue culture technique for the clonal propagation of onion using immature flower buds. Sci. Hort. 45: 31-36.

Purohit S, Dave, A and Kukda G 1994. Micropropagation of safed musli (Chlorophytum borivilianum), a rare Indian medicinal herb. Plant Cell Tiss. Org. Cult. 39: 93-96.

Robledo-Paz, A, Villalobos-Arámbula, V M and Jofre-Garfias AE 2000. Efficient plant regeneration of garlic (Allium Sativum L.) by root-tip culture. In vitro Cell. \& Develop. Biol. Plant 36(5): 416-419.

Sidhu AS, Kanwar JS and Chadha ML 1992. Seed production potential of different varieties of onion. Seed Tech. News. 22(1): 23.

Slabbert M, Bruyn, M, Ferreria, D and Pretorins J 1993. Regeneration of bulbets from twin scales of Crinum macowanii in vitro. Plant Cell Tiss. Org. Cult. 33: 133-141.

Snedecor GW and Cochran WG 1967. Statistical Methods. Oxford and IBH Publi Co Calcutta.

Wawrosch C, Malla P and Kopp B 2001. Micropropagation of Allium wallichii Kunth, a threathened medicinal plant of Nepal. In vitro Cell Dev. Biol. Plant 37: 555-557.

Xu Z, Um YC, Kim, CW, Lu1 G, Guo1 D, Liu H, Bah AA and Mao A 2008. Effect of plant growth regulators, temperature and sucrose on shoot proliferation from the stem disc of Chinese jiaotou (Allium chinense) and in vitro bulblet formation. Acta Physiol. Plantarum. 30(4): 521-528. 